\title{
ディジタル合成ホログラム用高解像度プリンタの高精度化
}

\section{A New High-Resolution Printer for Digitally Synthetic Holograms}

\author{
山中俊 介 $^{\dagger *}$, 正会員 松島 恭治†
}

Shunsuke Yamanaka ${ }^{\dagger *}$ and Kyoji Matsushima ${ }^{\dagger}$

\begin{abstract}
Our fringe printer for printing digitally synthetic holograms, which we reported in a previous article, was improved to increase its stability and resolution. The old model was capable of printing elliptical dots in a diameter of $2 \times 4 \mu \mathrm{m}$ by focusing the beam of a laser diode onto a hologram dry plate. However, active control to focus the laser beam was not taken into account in the design, and therefore, the resolution and the stability were limited. The new fringe printer has had mechanisms incorporated to detect surface undulations in the recording materials and control the beam waist only on the surface. These improvements made it possible to reduce the dot size to $1.5 \times 3 \mu \mathrm{m}$ and to keep the dots size within a large area.
\end{abstract}

キーワード : ホログラム, 3 次元立体画像, 計算機合成ホログラム, ディジタル合成ホログラム, CGH, 描画装置, プリンタ

\section{1. ま え がき}

計算機合成ホログラムとも呼ばれるディジタル合成ホロ グラムは, 計算機内に保持した物体モデル情報から物体光 を数值合成してホログラムを作製するものであり, すべて の生理的な立体感を満たす理想的な立体画像として知られ ている.また, 従来の写真型のホログラムとは異なるディ ジタル合成の利点として, 実在しない架空の 3 次元物体が 再生可能であることが挙げられる. しかしその反面, 干渉 縞の数值合成に要する計算量が莫大であり, またその干渉 縞を印刷/表示するのに数万 dpi 以上の高解像度デバイスを 必要とする問題点がある.このような高解像度印刷は電子 ビームリソグラフィ等の技術で可能であるが ${ }^{1)}$, 単なる画像 の印刷としては手間とコストがかかりすぎるため，簡易的 にはレーザプリンタ ${ }^{2)}$ やイメージセッタ ${ }^{3)}$, 写真縮小 ${ }^{4)}$ 等 が用いられ, 最近では CD-R ドライブ5) も用いられる。た だし，これらはいずれも解像度や描画精度が不充分である ため, 広い視域角を有するホログラムの作製は困難である.

我々は，主にディジタル合成ホログラムにおける物体光 波合成アルゴリズム ${ }^{6) 7)}$ の検証を目的として，ホログラム 乾板上に解像度約 $12,700 \mathrm{dpi}$ で, マルチレベルの濃度階調

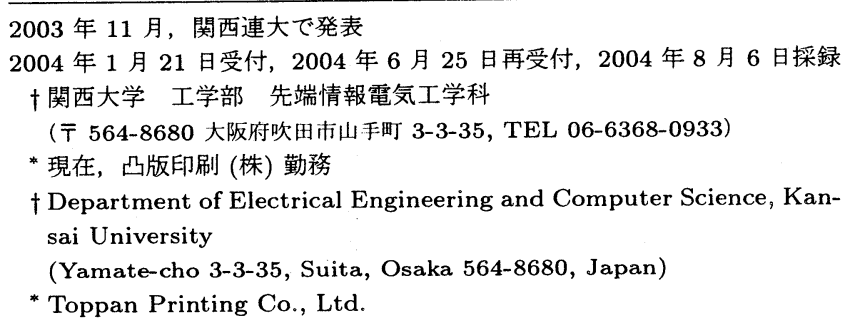

を持つ干渉縞を描画可能なホログラムプリンタをすでに報 告している ${ }^{8)}$.このプリンタでは, 出力を制御したレーザ ダイオード (LD) の出力光を定格開口数 (以下 N.A.) 0.4 の 対物レンズにより $2 \mu \mathrm{m} \times 4 \mu \mathrm{m}$ のスポットに集光して描画 している. その結果, 視域角 $18.2^{\circ} \times 9.1^{\circ}$ で再生が可能であ る. また，その描画線速度は $20 \mathrm{~mm} / \mathrm{s}$ であり, $8192 \times 4096$ ピクセルのホログラムを 2 時間半ほどで描画可能である. なお, この種のプリンタとしては, フォトリソグラフィ用 のレーザー直接描画装置が市販されているが, 波長帯が主 に紫外域であること, 高価であり温度・塺埃等の環境制御 が必要であること等から, 実験室で手軽にディジタルホロ グラムを乾板に描画できるものではない，また，一般にこ れらのレーザー直接描画装置では濃度階調を有する画像を 描画できないため, バイナリホログラムしか作成できない ことも難点である.

我々の既報のプリンタの問題として, 光軸方向の位置制 御を行っていないため, 乾板の厚さむらやステージの傾き, 乾板とステージ面の間に入る塵埃などの影響によっては, 乾板表面がビームウェストから外れてデフォーカスになる ことがあり，描画ドット径を安定して維持できないことが 挙げられる, また解像度向上のため N.A. を増加した場合, 焦点深度がさらに浅くなるため, この問題がさらに深刻に なる. 本論文では, 乾板表面高低差マッピングシステムと その高低差を補正するフォーカス制御系を有し，それに伴 う高 N.A. 化により高解像度化と安定性の向上を試みた新 しいプリンタの試作結果について報告する. 


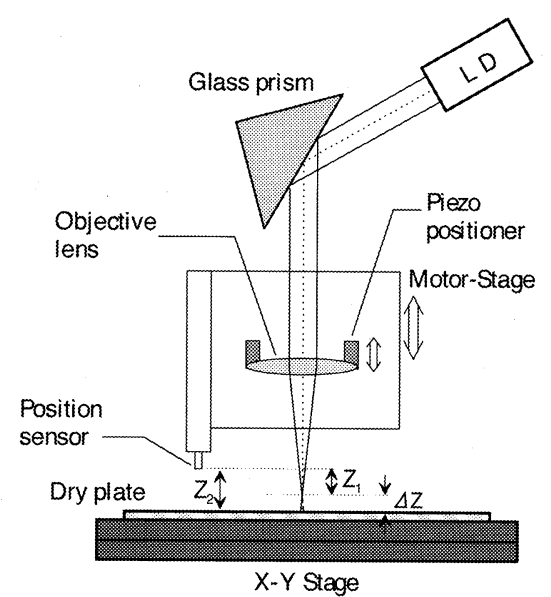

図 1 改良型ホログラムブリンタの構造 Schematic structure of the constructed printer.

\section{2. 改良型ホログラムプリンタの原理と構造}

改良型プリンタの構造を図 1 に示す。本プリンタは LD の出力光を無コートプリズムの表面反射によって減衰させ, 対物レンズでX-Y ステージ上のホログラム乾板表面に集光 してドットを描画する。従来型からの改良点として，まず 集光用対物レンズが N.A. $=0.4$ から 0.55 に向上したこと, また下記に述べる乾板表面高低差マッピングとフォーカス 制御光学系を組み込んだことが挙げられる.

\section{1 表面高低差マッピングとフォーカス制御}

図 1 に示したように，乾板表面の高低差を測定するため の変位センサを対物レンズ近傍に取り付けた。本研究で用 いるホログラム乾板は, 感光性があるため光ディスクなど で用いられる光学式の変位検出が不可能である。そのため, 接触型の差動トランス式変位センサを用い, 乾板表面に変 位センサの接触子を接触させ, 分解能 $0.2 \mu \mathrm{m}$ で乾板表面の 高低差を検出できる構造とした.

また，検出した表面高低差によるデフォーカスを補正す るため，対物レンズは PI-Polytec 社製のピエゾポジショ ナに取り付けた.このポジショナの印加電圧を制御するこ とにより, 分解能約 $10 \mathrm{~nm}$ で対物レンズを垂直方向に最大 $100 \mu \mathrm{m}$ 変位することが可能である. なお，対物レンズには ニコン製の 50 倍プラン長作動距離対物レンズを用いた。こ れらの変位センサとピエゾポジショナは, 分解能約 $0.1 \mu \mathrm{m}$, 繰り返し位置決め精度約 $\pm 0.5 \mu \mathrm{m}$ のモータステージ (以下 $\mathrm{Z}$ ステージ) に積載し, 全体を $\pm 7 \mathrm{~mm}$ 上下動可能な構造と した.

\section{2 フォーカス制御の原理}

本プリンタの制御系のブロック図を図 2 に示す。 X-Y, Z ステージおよび変位センサは RS-232C と USB のシリアル 通信, また LD とピエゾポジショナは $\mathrm{D} / \mathrm{A}$ コンバータに よる電圧制御となっている。

フォーカス制御では，まずピエゾポジショナに電圧を印 加しない状態で $\mathrm{Z}$ ステージを下降し, 基準位置での変位

$1666(120)$

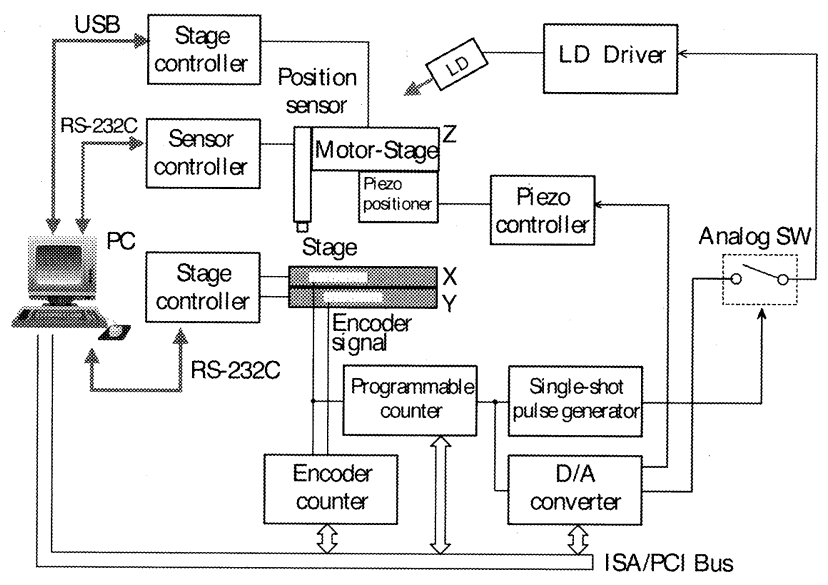

図 2 プリンタの制御回路

A block diagram of control circuits for the constructed printer.

センサ先端からホログラム乾板表面までの距離 $Z_{2}$ を測定 する. 一方, 同じ基準位置での変位センサ先端から対物レ ンズの焦点までの距離 $Z_{1}$ は一定であるので, $Z_{2}$ との差 $\Delta Z=Z_{2}-Z_{1}$ がゼロとなるようにピエゾポジショナを変 位させれば良い。しかしながら，変位センサの接触子の接 触点は，レーザの照射位置と同一ではなく，また変位セン サの構造と応答性からも測定と同時に描画を行うことは不 可能である。

そこで，表面高低差の測定とレーザ照射による描画を同 時に行うのではなく，描画開始以前に描画予定範囲内にお いて乾板表面の各点の高低差測定を繰り返し，そのデータ を蓄積した。この時, 描画するピクセルと同数の測定を行 うと莫大な時間を要するため, 描画範囲内で $9 \times 9$ 点程度 で高低差を測定し，測定点と測定点の間は線形補完を行う ことにより，描画範囲全体でピクセルごとの表面高低差の データを得た。

ホログラム描画時には，描画ピクセルごとにピエゾポジ ショナの $\Delta Z$ の変位に相当する制御電圧と $\mathrm{LD}$ 制御電圧を $\mathrm{D} / \mathrm{A}$ コンバータから出力し, 描画ピクセルごとに対物レ ンズの高さを変位させながら，レーザ光を乾板に照射した。 これにより，常にホログラム乾板表面に対物レンズの焦点 が一致した状態でレーザ光が照射され，乾板表面高さの変 化に関わらず描画ドット径を維持することが可能になる.

\section{3. 乾板高低差の測定とフォーカス制御の効果}

図 3 に乾板表面の高低差測定結果を示す。(a), (b) とも にホログラム乾板 PFG-03C の結果であり, 同一パッケー ジ内の異なった乾板を測定したものである. 最大高低差は, 試料 1 では $7.3 \mu \mathrm{m}$, 試料 2 では $6.2 \mu \mathrm{m}$ に達しており, 用 いた対物レンズの焦点深度 $1.05 \mu \mathrm{m}$ を超えているため, 対 物レンズの変位が必要であることがわかる。

間隔 $2 \mu \mathrm{m}$ で 8192 点のドット列を $\mathrm{X}$ 方向描画ラインに 沿って数本描画し, その始点, 中点, 終点付近を撮影した 顕微鏡写真を図 4 に示す. 図 4(b) に示すようにフォーカス 

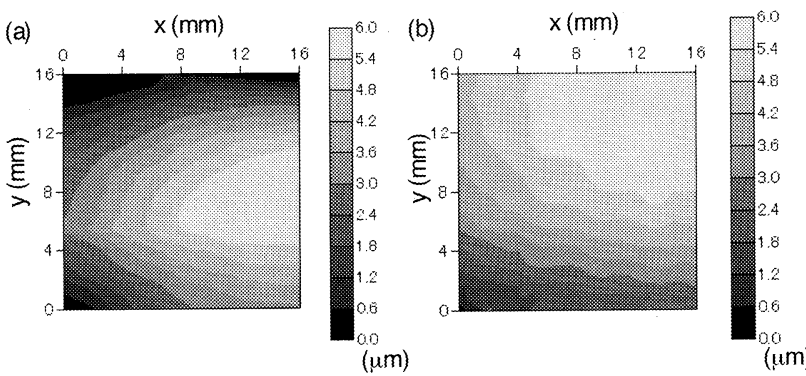

図 3 乾板表面の高低差測定結果. (a) 乾板試料 1, (b) 乾板 試料 2 .

Contour maps of the surface of two dry-plates. (a) Sample 1, (b) Sample 2.

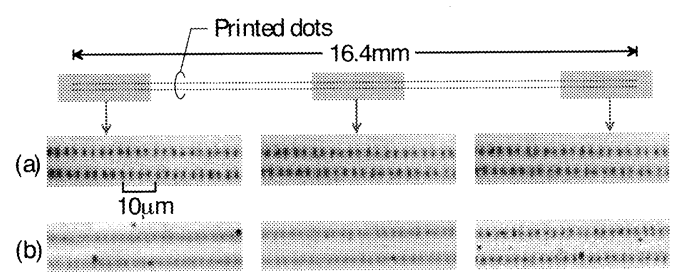

图 4 長いドット列の描画結果. (a) 改良型, (b) 従来型 Dots running for a long distance, printed by the new model (a) and the old model (b).

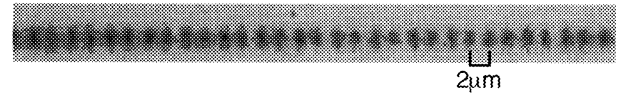

图 5 描画ドット列の顕微鏡写真

A photomicrograph of printed dots.

制御の無い従来型プリンタではこの範囲に渡ってドット径 を一定にすることは困難であったが，(a)に示した改良型 の結果では同一の描画ドット径を安定に維持出来ているこ とがわかる.

乾板高低差マッピングに必要な時間はマッピングの密度 と描画サイズによって変わるが，次節に示す $8192 \times 4096$ ピクセル $(12.3 \mathrm{~mm} \times 12.3 \mathrm{~mm})$ の標準的なホログラムで 9 $\times 9$ 点の高低差測定を行った場合，概小 15 分であった。

\section{4. 描画像とバイナリホログラム再生像}

図 5 に, 図 4 と同様にドット間隔 $2 \mu \mathrm{m}$ で描画したドット 列を拡大した顕微鏡写真を示す。この結果より，描画ドット 径が $\mathrm{X}$ 方向で $1.5 \mu \mathrm{m}$ 以下, $\mathrm{Y}$ 方向で $3 \mu \mathrm{m}$ 以下であること がわかった．図6(a) に示した 8 ビットグレイスケールのテ スト画像 $(240 \times 200$ ピクセル) を, 従来型のホログラムプ リンタで $2 \mu \mathrm{m} \times 4 \mu \mathrm{m}$ のドット間隔で描画した画像の顕微鏡 写真を図 6(b) に，また改良型プリンタを用いて同じテスト パターンを $1.5 \mu \mathrm{m} \times 3 \mu \mathrm{m}$ で描画した画像の顕微鏡写真を図 6(c)に示す.これらの画像はいずれも PFG-03C 乾板に描 画したもので，描画像の実サイズは (b) が $0.48 \times 0.8 \mathrm{~mm}^{2}$, (c) が $0.36 \times 0.6 \mathrm{~mm}^{2}$ である.これらの結果より，改良型 のホログラムプリンタでは, 従来型プリンタと同じ濃淡画 像をより高い解像度で描画可能であることを確認できた。

次に，本改良型プリンタを用いて同じ乾板上にドット間隔

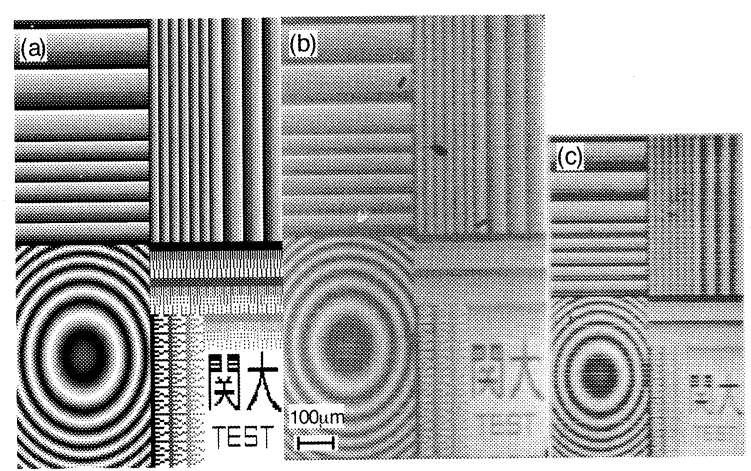

図 6 テスト画像の顕微鏡写真. (a) 原画像, (b) 従来型プリ ンタによる描画像, (c) 改良型プリンタの描画像.

A printed test pattern through a microscope: original image (a), printed image by the old model (b) and the new model (c).

表 1 作製したホログラムの主要なパラメータ

Parameters used for fabricating the hologram.

\begin{tabular}{lcl}
\hline \hline Number of pixels & $8192 \times 4096$ & \\
Reconstruction wavelength & 633 & $\mathrm{~nm}$ \\
Actual width of object & 6 & $\mathrm{~mm}$ \\
Density of point sources & 5000 & point $/ \mathrm{m}$ \\
\hline
\end{tabular}

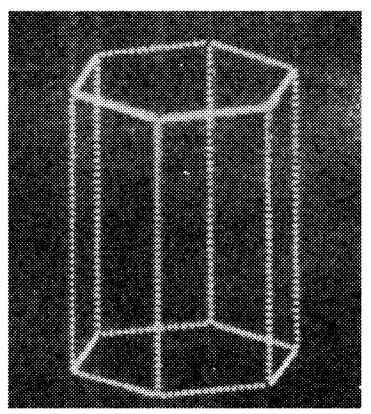

図 7 改良型プリンタにより描画したグレイレベルホログラム の光学再生像.

Optical reconstruction of a gray-level hologram printed by the constructed printer.

$1.5 \mu \mathrm{m} \times 3 \mu \mathrm{m}$ でグレイレベルホログラムの描画を試みた. 作製したホログラムのパラメータを表 1 に，その再生像を 図 7 に示す.このホログラムのサイズは $12.3 \times 12.3 \mathrm{~mm}^{2}$ で，ドット間隔から計算される視域角は水平方向 24.2 度, 垂直方向 12.1 度である. この結果より, 改良型のホログラ ムプリンタでもディジタル合成ホログラムの描画が可能で あることが確認できた.

\section{5. まと め}

従来報告していたディジタル合成ホログラム作成用プリ ンタの改良型プリンタを試作した。このプリンタは，従来 型と同様に線速度 $20 \mathrm{~mm} / \mathrm{s}$ でホログラム干渉縞を描画でき る一方, 集光レンズの開口数を従来型の 0.4 から 0.55 に増 加し, また乾板表面の高低差をサブミクロンでマッピング しそれを補正する機構を有している. その結果, 最小ドット 径は $\mathrm{X}$ 方向で $1.5 \mu \mathrm{m}$ 以下, $\mathrm{Y}$ 方向で $3 \mu \mathrm{m}$ 以下となり, 従 
来型プリンタと同様に，ドットごとに 8 ビット階調で濃度 を変化した干渉縞を直接描画可能である。これにより，描 画ホログラムの視域角は, 水平/垂直方向とも従来型と比較 して 1.33 倍に向上することができた.

本研究は, 日本学術振興会の科研費 (15300025) の助成 を得た. また, 本プリンタの試作にご協力いただいた関西 大学大学院生の宮内氏, 同学部生の山子, 栗林の各氏に深 謝致します。

\section{[文献]}

1) N. Yoshikawa, M. Itoh and T. Yatagai: "Binary computergenerated holograms for security applications from a synthetic double-exposure method by electron-beam lithography", Optics Lett., 23, pp. 1483-1485 (1998).

2) A. J. Lee and D. P. Casasent: "Computer generated hologram recording using a laser printer", Appl. Opt., 26, pp. 136-138 (1987).

3）梶木：“マルチ照明法による計算機合成バイナリホログラムの視域の拡 大”, 3 次元画像コンファレンス'99, pp. 293-294 (1999).

4）山岸, 吉川: “計算機合成ホログラムの広視域化”, 光学, 27, pp. 535-538 (1998).

5）坂本：“CD-R ディスクへの計算機合成ホログラムの描画”, HODIC Circular, 23, 4, pp. 13-16 (2003).

6) K. Matsushima and A. Kondoh: "Wave optical algorithm for creating digitally synthetic holograms of three-dimensional surface objects", SPIE Proc. Practical Holography XVII and Holographic Materials IX, \#5005, pp. 190-197 (2003).

7）近藤，松島：“シルエット近似を用いた全方向視差 CGH の隐面消去”，信 学論 D-II, J87-D-II, pp. 1487-1494 (2004).

8）松島, 上甲：“計算機合成ディスプレイホログラム用高解像度プリンタ”, 映情学誌, 56, pp. 1989-1994 (2002).

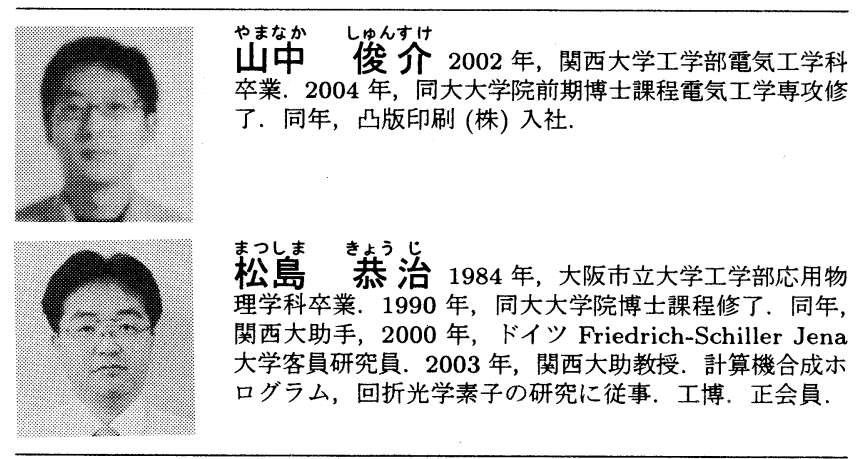

